\title{
БИЛИНГВИЗМ РОССИЙСКИХ НЕМЦЕВ (ПО ДАННЫМ СОЦИОЛОГИЧЕСКИХ ОПРОСОВ)*
}

На языковые процессы у российских немцев оказывают влияние различные факторы. Это внутренняя неоднородность этнической общности, дисперсный характер расселения большинства немцев, и в то же время-сохранение мест компактного проживания в сельской местности, различное понимание категории “родной язык”, возрастающая роль общественных организащий российских немцев, проводящих иеленаправленную политику по сохранению идентичности и немечкого языка. Под воздействием этих факторов язык российских немиев подвергся значительным трансформачиям. Русско-немечкий билингвизм, как особая черта языковой ситуации немцев, живущих в России, приобрел новые формыл. Немецкий язык постепенно утратил практические функции, он все больше становится этническим символом. А русский язык стал основным средством повседневного общения. Выбор языка, немецкого или русского, как инструмента общения, стал зависеть от конкретных ситуаций, языкового окружения, профессиональной сферы, участия в деятельности общественных организачий. Чтобы проследить динамику языковых проичессов, был использован метод социологического опроса, который позволяет глубже изучить особенности народа, находящегося на языковом пограничье. Социологические опросы немецкого населения проводятся Международным союзом немецкой культуры с периодичностью в 10 лет. В статье речь пойдет о результатах двух последних, наиболее масштабных опросов, которые были проведень в 2009 и 2020 годах. Общей иелью опросов стал анализ состояния и тенденций этнокультурного развития российских немцев. Отдельный блок вопросов, который нашел отражение в статье, был посвящен языку российских немиев. Внимание авторов было обращено на такие показатели, как признание языка родным, уровень владения тем или иным языком, сферы и формы использования языков, оченка преподавания немецккого языка в образовательных учреждениях. Представленная в статье динамика этноязыковых проиессов позволяет оценить языковую ситуацию и дать прогноз развитию русско-немецкого билингвизма российских немцеев.

Смирнова Татьяна Борисовна - д.и.н., проректор по учебной работе, Омский государственный университет им. Ф.М. Достоевского (644053 Омск, Нефтезаводская ул., 11). Эл. почта: SmirnovaTB@omsu.ru

Шлегель Елена Александровна - помощник проректора по учебной работе, аспирант, Омский государственный университет им. Ф.М. Достоевского (644053 Омск, Нефтезаводская ул., 11). Эл. почта: ShlegelEA@omsu.ru

*Исследование выполнено при финансовой поддержке РФФИ в рамках научного проекта № 1729-09152 "Русский язык, языки народов России и российская идентичность: антропологические подходы к изучению языковой ситуации и этнокультурной политики”. 
Ключевые слова: билингвизм, российские немџы, этноязыковые процессы, соииологические опросы

Ссылка при цитировании: Смирнова Т.Б., Шлегель Е.A. Билингвизм российских немцев (по данным социологических опросов) // Вестник антропологии, 2021. № 1 (53). С.

Российские немцы, проживающие дисперсно на территории Российской Федерации, представляют собой многообразную этническую общность. После издания в 1763 г. Манифеста Екатерины II “О дозволении всем иностранцам, в Россию въезжающим, поселяться в которых Губерниях они пожелают и о дарованных им правах”, на территорию Российской империи массово переселились немецкие колонисты из различных германских земель. Немецкие крестьяне представляли собой отдельные группы, отличающиеся между собой культурными особенностями, вероисповеданием и языком. К примеру, бывшее немецкое село Прайс Саратовской области являлось местом, куда переселились немцы сразу из 129 местностей Германии, создав тем самым уникальную диалектную разноголосицу в пределах всего лишь одного населенного пункта (Минор 2014: 4). Дальнейшие исторические события наложили отпечаток на формирование сложной этнической идентичности у немцев России. Помимо привычных обозначений “российские немцы”, “немцы России”, “этнические немцы”, широко распространены и такие определения немцев, как “поволжские”, “волынские”, “закавказские”, “сибирские”, “казахстанские”, “советские” и т.д. Те или иные определения немцев возникали в различные периоды истории, закреплялись, исчезали, а некоторые из них продолжают существовать и сейчас ${ }^{1}$.

Споры в научных кругах относительно терминологии, привели к тому, что этноним “российские немцы” стали использовать в отношении всех немцев, проживавших в свое время в Российской империи, Советском Союзе, а позже - и на всем постсоветском пространстве. Это позволило расширить исследовательское поле и привлечь большее внимание к существующим проблемам народа. Из всех стран бывшего Советского Союза, Российская Федерация лидирует по количеству проживающих здесь немцев. Но так было не всегда. По данным Всесоюзной переписи населения 1989 г. наибольшее количество немцев (957 тыс. человек) проживало в Казахской ССР, куда они были депортированы в 1941 г. В РСФСР числилось 842 тыс. немцев. Общая их численность в 1989 г. составила более 2 млн человек (Национальный состав 1989).

В середине 1990-х гг. ситуация очень быстро изменилась, благодаря массовой эмиграции в Германию. В 2002 г. перепись населения зафиксировала на территории России 597 тыс. немцев (Национальный состав 2002). Последняя Всероссийская перепись населения 2010 г. - 394 тыс. человек, указавших немецкую национальность (Национальный состав и владение 2010). В Казахстане сейчас насчитывается чуть более 178 тыс. немцев (Итоги переписи 2009). В остальных странах бывшего СССР численность немцев не превышает 35 тыс. человек, и это количество ежегодно уменьшается.

Основными регионами проживания немцев в России стали Алтайский край (50 701) и Омская область (50 055 немцев). На обеих территориях в 1991 и 1992 гг. были образованы Немецкие национальные районы с административными центрами в с. Гальбштадт и с. Азово. Места компактного проживания немцев продолжают су-

\footnotetext{
${ }^{1}$ Подробнее об этом см.: Смирнова, Киссер 2017: 44-53.
} 
ществовать, хотя и в гораздо меньших масштабах, также в Оренбургской, Томской и ряде других областей (Реестр 2020).

Различные, зачастую противоречивые обстоятельства (например, наличие компактных мест поселения, и в то же время - дисперсное проживание большинства немцев, современные этноязыковые программы, направленные на поддержку немецкого языка, и в то же время - низкая мотивация его изучения), способствовали формированию уникальной языковой ситуации у российских немцев. Современные исследователи признают русско-немецкий билингвизм неотъемлемой чертой языковых процессов у российских немцев.

Билингвизму немцев были посвящены многочисленные исследования в советский период. Лингвисты и этнографы, часть из которых были выходцами из бывшей Республики немцев Поволжья, занимались изучением диалектных форм немецкого языка среди местных жителей. Первые целенаправленные экспедиции по сбору лингвистического, фольклорного и этнографического материала были предприняты Г.Г. Дингесом (Дингес 1925), А.П. Дульзоном (Дульзон 1941), В.М. Жирмунским (Жирмунский 1956). В 1960-е гг. работы по немецкой диалектологии были возобновлены после долгого перерыва. Г.Г. Едиг в это время исследует нижненемецкие диалекты Алтайского края. Позже его ученики Л.И. Москалюк (Москалюк) в г. Барнауле и В.А. Дятлова (Дятлова 1988) в г. Красноярске, Н.Г. Беренд (Berend 2011) продолжили изучение немецких островных говоров, уделяя внимание непосредственно феномену билингвизма российских немцев. Диалектам и вопросам межъязыковой коммуникации посвятили свои работы в Волгоградской области Н.А. Фролова (Фролова 1999), в Томской области О.А. Александров, З.М. Богословская (Александров, Богословская 2008), в Кировской области О.В. Байкова (Байкова 2012), в Саратовской области А.Я. Минор (Минор 2016) и т.д. Практически в каждом регионе с компактным проживанием немцев сложились уникальные языковые варианты, которые являются объектом изучения современных лингвистов и этнографов.

Исследователи в своих работах обращают внимание на разновидности коммуникаций немцев различных возрастов в повседневной жизни. Полевые материалы посредством анкетирования, интервью собираются преимущественно в сельской местности, где наилучшим образом сохраняется этническая идентичность и язык российских немцев. Но говоря о сохранении диалектного языка, нужно подчеркнуть, что на современном этапе он используется преимущественно старшим поколением, проживающем в бывших немецких населенных пунктах или нынешних местах компактного проживания немцев. Владение немецким языком среди представителей среднего возраста зависит от установок внутри семьи на передачу родного немецкого языка детям. Для многих семей, особенно созданных между представителями разных народов, передача языка не являлась обязательной установкой, а ввиду исторических событий, наоборот, происходила целенаправленная ассимиляция в среде русского населения. Подобные условия способствовали формированию русско-немецкого двуязычия российских немцев.

Не нужно проводить каких-либо глобальных исследований, чтобы констатировать, изменения этноязыковой ситуации среди российских немцев за последние 10 лет, а за 20 или 30 лет - эти изменения были радикальными. Достаточно посмотреть на динамику признания немецкого языка в качестве родного, по данным всеобщих переписей населения в Российской империи, в СССР и позже - в России (Табл. 1). 
Таблица 1

Динамика признания немецкого языка родным в процентном соотношении (по данным переписей населения)

\begin{tabular}{|c|c|}
\hline Год переписи & Доля признавших немецкий язык родным языком \\
\hline 1897 & $100 \%$ \\
\hline 1926 & $94,9 \%$ \\
\hline 1939 & $88,4 \%$ \\
\hline 1959 & $75,0 \%$ \\
\hline 1970 & $66,8 \%$ \\
\hline 1979 & $57,0 \%$ \\
\hline 1989 & $48,8 \%^{1}$ \\
\hline 2002 & $32,0 \%{ }^{2}$ \\
\hline 2010 & $10,8 \%^{3}$ \\
\hline
\end{tabular}

О том, как наиболее полно и качественно отразить языковую ситуацию в стране посредством переписи населения, велись долгие дискуссии. В пользу изьятия вопроса о родном языке приводились доказательства того, что признание языка родным - это скорее психологическая категория, которая связана с языком детства, с материнским языком, и реальную ситуацию он не отображает. В настоящее время более важное значение приобретает категория “знание и владение языком”. Так, по данным переписи 2002 г. владели немецким языком 189 тыс. немцев или 32\% от опрошенных, данные же 2010 г. показали, что число владеющих немецким языком снизилось до 86 тыс. человек. Это составляет 22\% от указавших владение языком немцев. Так как в перепись 2010 г. вопрос о родном языке был возвращен, мы имеем данные о том, что для 45 тыс. человек немецкий язык был родным, но в это число, помимо немцев, входят люди других национальностей, а также те, кто не указал свою национальную принадлежность. Согласно переписи 2010 г. 89\% немцев считают родным языком русский язык, и 0,2\% немцев считают родными другие языки - украинский, татарский, коми и т.д.

Немцы в Российской Федерации являются одним из тех народов, для которого возможность указать два родных языка в рамках переписи, имеет принципиальное значение. Падение доли тех, кто признает немецкий язык в качестве родного, обусловлено не только объективными причинами, к которым относятся эмиграции, ассимиляция, уход из жизни старшего поколения - носителей языка, большое количество смешанных семей, в которых с детьми дома говорят только по-русски, но и тем, что существует разное понимание категории “родной язык”. Все больше с родным языком у немцев ассоциируется язык повседневного общения, то есть русский.

\footnotetext{
${ }^{1} \mathrm{~B} \mathrm{РСФСР}-42 \%$.

${ }^{2}$ В переписи 2002 г. вопрос о родном языке был изъят, вместо него задавался вопрос о владении языками.

${ }^{3}$ Родным языком немецкий язык назвали 42 тыс. человек, или $11 \%$ от указавших родной язык немцев.
} 
Идеальной моделью при проведении переписи населения явилась бы расширенная версия опросного листа, в который были бы включены дополнительные вопросы о языковой ситуации в стране, а также предоставление гражданам возможности указания нескольких родных языков (как и нескольких вариантов национальности/этнической принадлежности). Следующая перепись будет давать такую возможность, но пока этого не произошло, исследователи этноязыковых процессов у различных народов проводят специальные социологические опросы и языковые мониторинги, предоставляющие дополнительную информацию о языке в его динамике.

Подобные социологические опросы у российских немцев, в которых в той или иной степени затрагиваются вопросы языка, проводились несколько раз, но самые крупные, о которых пойдет речь далее - в 2009 и 2020 гг.

В 2009 г. в рамках федеральной целевой программы “Социально-экономическое и этнокультурное развитие российских немцев на 2008-2012 гг.” был проведен социологический опрос, ставивший своей целью выявление тенденций этнокультурного развития российских немцев. Так как изменения к этому времени в среде этнической группы произошли во всех сферах жизнедеятельности, то и проанализировать их в общем контексте развития народа оказалось преимущественно важным. Опрос был инициирован Ассоциацией общественных объединений "Международный союз немецкой культуры” (МСНК) и проводился во всех Федеральных округах России, пропорционально численности немцев в этих округах.

По итогам опроса удалось проанализировать состояние таких компонентов, как этнодемографическая и социальная структура немецкого населения, этническая идентичность, родной язык, культура, межэтнические установки и миграционная ситуация. Объем выборки, базирующейся на отборе респондентов по месту расселения и типу поселения, полу и возрасту, составил 1500 респондентов.

Всего в опросном листе было 75 вопросов, из них непосредственно языку было посвящено 13 вопросов. Вопросы задавались следующие: какой язык Вы считаете родным; в какой степени Вы владеете языками; как Вы используете языки, которыми владеете; если Вы владеете немецким языком, то в какой форме; какой именно диалект Вы знаете; как часто Вы используете немецкий язык; где Вы изучаете (или изучали) немецкий язык; на каких языках Вы обычно читаете. Вопросы, касающиеся преподавания немецкого языка в учебных учреждениях звучали так: как Вы считаете, нужно ли детям российских немцев преподавать в школе немецкий; если “да”, то укажите наиболее предпочтительную форму преподавания. И, наконец, финальные вопросы: на каком языке Вы предпочли бы смотреть фильмы, телепередачи, спектакли, концерты, если есть возможность выбора; может ли человек, не знающий немецкого языка, быть российским немцем; насколько важно российским немцам сохранять немецкий язык.

Результаты опроса были следующими: из 1500 респондентов немецкий язык признали в качестве родного 451 человек (31\%), русский - 885 (60\%), оба языка - 135 человек (9\%), другой язык - 4 человека (менее $1 \%$ ). При этом свободно владели немецким языком 454 респондента или $30 \%$; не владели совсем - 113 человек или $8 \%$. Русским языком свободно владели 96\% респондентов. Опрос 2009 г. показал, что только 4 человека из 1500 опрошенных не владеют русским языком, 7 человек плохо понимают и говорят по-русски, 16 человек испытывают определенные трудности при разговоре на русском языке (Смирнова 2010: 37). Менее 1\% не владеющих 
русским языком - это некоторые люди пожилого возраста из сельских глубинок. У них отсутствовала мобильность за пределы проживания, и чаще всего они не имели возможности получить образование в свое время. По результатам данного опроса видно, что еще сохраняется зависимость между признанием языка родным и владением им, примерно $30 \%$ респондентов считают немецкий язык родным, и столько же им владеет. Забегая вперед, скажем, что последние данные показали, что на сегодняшний день владеет немецким языком уже больше немцев, чем признают его в качестве родного. Это подтверждает тот факт, что немецкий язык перешел в категорию этнического символа, что с одной стороны вызывает определенное желание отдать должное языку своих предков - и выучить его, а с другой стороны ввиду того, что немецкий язык не является языком первого говорения для большинства опрошенных, он не ассоциируется с родным языком.

Сферы употребления языков были также проанализированы в рамках опроса. Из результатов видно, что респонденты в большей степени выбирают немецкий язык в качестве инструмента общения при поездках в Германию $(60 \%)$, при посещении Центров немецкой культуры (39\%), во время переписки с родными (20\%), во время общения с родителями (18\%) и супругами (7\%). Из других сфер немецкий язык почти исчезает. Русский же используют, прежде всего, на работе $89 \%$ респондентов, с друзьями и соседями говорят 79\% опрошенных, с супругами говорят по-русски $78 \%$, с детьми $-76 \%$, с родителями - $62 \%$. В меньшей степени русский язык используют при поездках в Германию - $21 \%$ респондентов и при посещении Центров немецкой культуры - 29\%. Попеременно используют оба языка в большей степени в Центрах - 32\% опрошенных, с родителями - $20 \%$, с детьми и в переписке используют оба языка по 19\%. Однако все остальные сферы являются также двуязычными, в той или иной степени. Нет сфер общения, в которых разговаривали бы только по-русски или только по-немецки.

Формы использования языка могут быть двух видов - литературный язык или диалект. Согласно опросу, литературным языком владело 44\% респондентов, диалектным языком - 37\%, при этом обеими формами владели более $19 \%$ респондентов, поэтому нельзя сказать, что литературный язык в данном случае преобладает, хотя его позиции постепенно с этого времени начинают укрепляться ввиду различных программ поддержки, популяризации языка и т.д. Наиболее известным диалектным языком является платтдойч - платский диалект, распространенный в среде меннонитского населения страны. Данный диалект занимает наиболее устойчивые позиции в виду общинного, замкнутого характера проживания его носителей. Кроме этого диалект имеет развитую письменную традицию (Либерт 2019). К числу наиболее употребляемых диалектов относятся также швабский и поволжский.

Важным показателем билингвальной составляющей народа остается частота употребления языков. То, что русский язык все немцы без исключения используют ежедневно - факт, немецким же языком пользуются повседневно только $21 \%$ опрошенных, несколько раз в неделю - 27\%, не используют немецкий вовсе - 17\% опрошенных. Те, кто хоть как-то знает язык, а таких большинство - приобрели эти навыки во время школьного обучения (61\%), остальным язык был передан в детстве (54\%), и во время учебы в высшем учебном заведении (23\%). Некоторые учили язык на специализированных курсах (17\%), самостоятельно $(10 \%)$ или в национально-культурном центре (12\%). 
Ввиду того, что существует большая разница между литературным немецким языком и его диалектной формой, большинство респондентов старшего возраста не готовы читать литературу, газеты, смотреть телепередачи и фильмы на немецком языке, которым зачастую они не владеют в достаточной мере. Среднее же и молодое поколение делает выбор в пользу русского языка из-за недостаточной компетентности в немецком языке. Поэтому результаты ответов на вопрос: “На каком языке Вы предпочли бы смотреть фильмы, телепередачи, спектакли, концерты”, распределились следующим образом: на русском $-74 \%$, на немецком - $16 \%$, на обоих языках $-9 \%$, на другом $-1 \%$.

Отдельный блок вопросов характеризовал отношение к школьному преподаванию немецкого языка. То, что есть необходимость изучать немецкий язык в школе, ответило 93\% респондентов. При этом лучше, если язык будет преподаваться с первого класса и до окончания школы в качестве родного. Этот вариант выбрало 37\% опрошенных. Остальные ответы распределились между вариантами создания классов с углубленным изучением языка (33\%), создания факультативов для желающих (15\%) или преподавания немецкого как иностранного (14\%). Ответы в пользу углубленного изучения немецкого языка свидетельствуют о признании того факта, что немецкий в качестве иностранного в большинстве случаев преподается на недостаточном уровне, в отличие от того времени, когда немецкий изучался как родной в общеобразовательных школах. Кроме того, немецкий язык не выдерживает конкуренции с английским языком при выборе иностранного языка для изучения.

Отвечая по 10-балльной шкале на вопрос о степени важности сохранения немецкого языка среди российских немцев, 55\% респондентов выбрали максимальную оценку. Этот ответ явился наиболее популярным (из 1500 тыс. человек его выбрало 779 респондентов), средняя же оценка колебалась в пределах 8,5 баллов, что также является высоким показателем. Но знание или незнание языка у российских немцев при этом не является важнейшим условием отождествления себя с этнической группой. Немцем, по мнению многих респондентов, человек является по рождению, а не по тому, знает ли он немецкий язык, ведь условия сохранения языка в семье были разными. Так, отвечая на вопрос о том, может ли человек, не знающий немецкого языка быть российским немцем, утвердительно ответили 78\% респондентов, отрицательно $11 \%$, затруднились ответить $11 \%$.

Таким образом, результаты опроса 2009 г. свидетельствовали о том, что русско-немецкий билингвизм являлся неотъемлемой чертой языковых процессов российских немцев. Превалирование русского языка в жизни немцев были обусловлены объективными причинами, к которым относится необходимость адаптации в иноэтничном окружении, стремление снять с себя клеймо “врага народа", что в свою очередь предопределило установку на минимальное использование немецкого языка и нежелания передавать язык подрастающему поколению. Но опрос показал, что из большинства сфер жизнедеятельности российских немцев немецкий язык никуда не ушел, хотя его позиции и существенно снизились. Им владеют в той или иной степени, его используют с определенной периодичностью, его хотят сохранить в школьном образовании. Большим фактором в сохранении немецкого языка послужило и развитие сети общественных организаций российских немцев, которые к моменту проведения опроса развернули широкую деятельность по актуализации этнического самосознания немцев. Этнокультурные и языковые проекты способствовали возрастанию интереса к немецкому языку, истории и культуре своего народа, а бесплатные языковые курсы на базе Центров встреч повлияли, 
как минимум на то, что немцы стали использовать язык еженедельно, другие же вовсе пришли к пониманию в качестве родного - именно немецкого языка.

Между опросами 2009 и 2020 гг. был проведен промежуточный языковой мониторинг в 2015 г. среди посетителей Центров немецкой культуры (Смирнова 2015). Из 1200 заполненных анкет было отобрано 1000 анкет, которые соответствовали географии расселения немцев в России, гендерному и возрастному составу людей, посещающих Центры немецкой культуры. Задачами мониторинга являлись оценка эффективности реализуемых программ в сфере языковой работы, а также определение основных тенденции развития языковых процессов. Родным языком немецкий назвали 28\% респондентов, а свободно владело им же - 20\% опрошенных. $99 \%$ немцев свободно владело русским языком (Смирнова 2015: 25). Данный опрос подтвердил и тот факт, что все сферы общения российских немцев остаются двуязычными. Случаи, когда немцы практикуют употребление только немецкого или только русского языка малочисленны. В принципе, результаты этого социологического исследования еще раз подтвердили данные опроса 2009 г., и не выявили существенных изменений этноязыковой ситуации в какую-либо сторону.

В 2020 г. появилась возможность провести масштабный социологический опрос повторно и обратить внимание на те изменения, которые произошли в языке российских немцев спустя 10 лет. Финансовая поддержка при проведении опроса была оказана со стороны МСНК. С привлечением социологов, историков, этнографов со всей страны удалось собрать 1000 анкет, соответствующих выборке. За генеральную совокупность было взято общее количество немцев в Российской Федерации, согласно переписи населения 2010 г.

В целом, по данным опроса результаты были получены следующие:

Считают родным немецкий язык - $14 \%$ респондентов. Русский язык назвали родным 42\%. Почти столько же (44\%) респондентов сказали, что считают родным оба языка, и русский, и немецкий. Один человек сказал, что ни тот, ни другой. Тот факт, что более $40 \%$ респондентов указали в качестве родного два языка, говорит о том, что такую возможность - указывать несколько языков, нужно дать и при проведении переписи населения.

Российские немцы сегодня владеют русским языком лучше, чем немецким. В той или иной степени, им владеют все опрошенные. Так, 97\% респондентов сказали, что владеют русским языком свободно. Хорошо понимают и могут говорить на русском языке, но не владеют свободно - 3\%. Один человек сказал, что плохо понимает и плохо говорит по-русски. Это женщина 80 лет, которая долго жила в Германии, но вернулась в Россию. Сейчас она живет в деревне на Алтае.

Немецким языком свободно владеют $26 \%$, то есть свободно владеющих немецким языком почти в 4 раза меньше, чем свободно владеющих русским языком. Самый распространенный вариант владения немецким языком - это “хорошо понимаю, могу изъясняться" - 35\%. Владеют немецким языком, но плохо понимают и плохо говорят $20 \%$ опрошенных немцев. $14 \%$ не говорят, но немного понимают немецкий язык. Наконец, 5\% российских немцев не владеют немецким языком совсем.

Условия, в которых развивался немецкий язык в России, нельзя назвать благоприятными: первоначальное существование в форме разнообразных диалектов и слабое распространение немецкого литературного (стандартного) языка, прекращение школьного преподавания на немецком языке в 1938 г., ликвидация АССР немцев Поволжья 
и соответствующих структур преподавания и издания на немецком языке, признание немецкого языка в СССР только в качестве иностранного, последующая языковая ассимиляция. В этих условиях надо признать этот результат не таким уж и плохим, поскольку 95\% опрошенных владеют немецким языком, в той или иной степени.

$12 \%$ опрошенных владеют другими языками, кроме русского и немецкого, причем $2 \%$ владеют ими свободно. В основном это английский язык. Респондентами были указаны также другие иностранные языки, а из языков народов России несколько раз упоминались украинский язык и коми.

Весьма значимой при характеристике этноязыковых процессов является сфера применения немецкого языка, ответ на вопрос о том, где и когда немцы говорят по-немецки. Если исключить употребление немецкого языка во время поездок в Германию (там вынуждены говорить по-немецки почти все), то чаще всего немецкий язык используется в Центрах немецкой культуры - так ответили $41 \%$ респондентов, и на нем говорят (говорили раньше) с родителями $-56 \%$.

В других сферах общения немецкий язык употребляется гораздо реже: по-немецки говорят с супругами - 23\%, с детьми - 26\%. Еще реже немецкий язык употребляется в общении с друзьями (24\%), в социальных сетях $(13 \%)$ и на работе $(11 \%)$. Используют немецкий язык в переписке $19 \%$ опрошенных.

Следует подчеркнуть, что все без исключения сферы общения стали двуязычными, владеющие немецким языком редко практикуют употребление только немецкого (или исключительно русского языка). Чаще всего респонденты отвечали: “Говорим и по-немецки, и по-русски”, а выбор языка зависел от конкретной ситуации. Двуязычие всех сфер общения связано не только с ассимиляционными процессами - в этом случае зависимость прямая, но и с тем, что устаревшие диалектные формы, которые в основном употребляются немцами в обычной речи, не отвечают потребностям времени, например, в производственной сфере общения.

Исторические условия развития немецкого языка в России привели к тому, что позиции литературного немецкого языка, хотя и укрепились значительно в последние годы, но пока они не являются однозначно преобладающими. Так, при ответе на вопрос, в какой форме, диалектной или литературной, владеющие немецким языком его знают, 52\% сказали, что в форме литературного языка, $21 \%$ - в форме диалекта и $20 \%$ респондентов сказали, что владеют и диалектом, и литературным языком. $7 \%$ затруднились с ответом.

Назвали диалект, которым они владеют, 29\% опрошенных. Больше всего владеют диалектом платтдойч (часто встречающийся вариант - меннонитским диалектом) - 86 человек из тысячи опрошенных. На втором месте - “местный” диалект (51 чел.). Люди не могут назвать конкретный диалект, просто говорят, что здесь все так говорили, так говорили родители. Как вариант называют диалект по своему селу: “камышинский” (жители деревни Камыши), “побочинский” (с. Побочино), “подсосновский” (с. Подсосоново) и др. 48 чел. сказали, что знают швабский диалект, 28 чел. - поволжский диалект, 24 чел. - баварский диалект, 10 чел. - гессенский диалект. Для некоторых людей характерно то, что они связывают диалект и религию 26 чел. сказали, что знают католический диалект, и 13 чел. - лютеранский. 1-2 чел. назвали такие диалекты, как пфальцский, вестфальский, кельнский, волынский, сарептский, южнонемецкий, средненемецкий. 
Частота употребления немецкого языка зависит от самой возможности этого употребления. Эта возможность выше в местах компактного проживания немцев, в сельской местности, в тех семьях, где сохраняется язык, в тех районах, где развита сеть национально-культурных центров и эти центры активно функционируют и т.д. В целом, частота употребления немецкого языка следующая: каждый день используют в общении немецкий язык $27 \%$ респондентов, несколько раз в неделю - $28 \%$, несколько раз месяц - 19\%, несколько раз в год - 17\%. Совсем никогда не используют немецкий язык $10 \%$ респондентов.

Чуть более половины респондентов (58\%) знают язык с детства, на немецком говорили в их семьях (именно здесь - преимущественно на диалектах), остальные уже изучали немецкий язык в школе (в основном как иностранный) - 51\%, в вузе (22\%), на языковых курсах (17\%), в национально-культурном центре (21\%). Некоторые учили язык самостоятельно (14\%), но в принципе, очевидна роль образовательных структур в формировании языковой компетенции российских немцев. Школа и высшие учебные заведения - это те структуры, которые в наибольшей степени способствуют сохранению немецкого языка.

Таким образом, русско-немецкое двуязычие является наиболее определяющей чертой при характеристике развития языковых процессов у немецкого населения России. Принято различать экстенсивную и интенсивную тенденции развития двуязычия. В первом случае двуязычие распространяется вширь, то есть вторым языком овладевает все больше представителей этнической группы. Во втором случае проявляется тенденция к “углублению” двуязычия посредством лучшего овладения русским языком с использованием его во внутриэтническом общении. У немцев наблюдаются обе эти тенденции, однако, в последнее время необходимо отметить возрастание роли русского языка во всех сферах речевой деятельности.

Об этом свидетельствует и предпочитаемый язык при чтении периодических изданий и литературы. Если на русском языке читают практически все респонденты, то на немецком языке газеты и журналы читают $27 \%$ опрошенных, учебную и научную литературу $-13 \%$, художественную литературу - $13 \%$, тексты, сайты в интернете $-26 \%$. Около 3\% читают на других языках, в основном на английском языке, в интернете $5 \%$. Учитывая ответы о газетах, журналах и текстах в интернете, можно сделать вывод о том, что около четверти российских немцев регулярно читают на немецком языке.

Если есть возможность выбора, то половина опрошенных (50\%) предпочитают смотреть фильмы, спектакли, концерты, телевизионные передачи и на русском, и на немецком языках, 46\% - только на русском языке, Выбрали бы фильмы и передачи только на немецком языке $3 \%$. Выбрали другой ответ $1 \%$ (на английском языке, или - на языке оригинала, то есть если фильм русский, то его лучше смотреть на русском языке, а если немецкий - соответственно на немецком).

На развитие языковой ситуации большое влияние оказывает установка населения на язык школьного обучения. Она определяется по двум параметрам: во-первых, по степени осознания необходимости преподавания детям языка своей национальности, и, во-вторых, по выбору типа школы для своих детей в проективной ситуации. Так, при ответе на вопрос “Как Вы считаете, нужно ли детям российских немцев преподавать в школе немецкий язык?” утвердительно ответили 92\%, затруднились ответить 7\%, отрицательно ответили менее $1 \%$ респондентов. Таким образом, подавляющее большинство немцев считает, что в школах необходимо преподавать не- 
мецкий язык, причем ситуация в этом вопросе очень стабильная. По результатам опроса 2009 г. ответы были такие же, с разницей в десятые доли процента.

Ответившим утвердительно на этот вопрос, предлагалось указать наиболее предпочтительную форму преподавания немецкого языка. Две наибольших группы респондентов считают, что преподавать немецкий язык нужно в качестве родного с первого класса и до окончания школы (39\%), или - что необходимо создавать классы с углубленным изучением немецкого языка (20\%). Что нужно преподавать немецкий язык в качестве иностранного языка в обычном формате - считают 14\% респондентов, что нужно создавать факультативы для желающих - $12 \%$. Немецкий язык должен преподаваться в качестве родного в начальной школе - 6\%. Надо сказать, что именно эта форма преподавания этнического языка наиболее распространена в местах компактного проживания немецкого меньшинства в странах Евросоюза (в Тироле, Венгрии и других местах), но в России она не принята. На другие формы указали $2 \%$ респондентов. Таким образом, подавляющее большинство высказывается за расширение преподавания немецкого языка по сравнению с существующей ситуацией. В условиях, когда место первого иностранного языка в преподавании прочно занял английский язык, ситуацию с преподаванием немецкого можно охарактеризовать как очень сложную.

Респондентам предлагалось на личном опыте оценить, насколько качественно преподавался немецкий язык тем, кто изучал его в школе, колледже (техникуме) или вузе. Предлагалось дать оценку по 10-бальной шкале. Большинство респондентов поставили оценку 8 баллов в школе и вузе, 9 баллов - в колледже. Около трети респондентов поставили наивысшую оценку в 10 баллов школьному преподаванию немецкого языка. Низких оценок в 1-3 балла очень мало, около 2-3\%. Таким образом, уровень преподавания оценивается достаточно высоко. Основную проблему, по мнению респондентов, представляет не уровень преподавания, а вытеснение немецкого языка английским. Это приводит к тому, что уменьшается количество учителей немецкого языка, сокращается подготовка таких учителей в вузах, становится все меньше специализированных кафедр. Соответственно, преподавание немецкого языка становится менее распространенным, все более популярными в качестве второго иностранного языка сейчас являются китайский, японский, испанский.

Почти 40\% опрошенных изучают немецкий язык. Самый распространенный ответ о том, где респонденты изучают немецкий язык - в национально-культурном центре, Российско-Немецком доме. Так ответили $21 \%$ респондентов. Популярность курсов немецкого языка в национально-культурных центрах объясняется тем, что они доступны многим немцам, эти курсы есть практически во всех городах, в сельской местности в тех местах, где немцы живут компактно. Эти курсы бесплатные, они финансируются при поддержке Германии. Их программы обучения языку адаптированы к российским условиям. Многие посещают курсы немецкого языка, потому что это место, где можно прикоснуться к немецкой культуре, здесь можно провести время с детьми, взять книги в библиотеке, здесь проводятся национальные праздники. Изучают немецкий язык как иностранный в университете 4\% опрошенных, изучают в Институте Гёте - 3\%, на открытых платформах в интернете - 2\%. Кроме того, 14\% респондентов немецкий язык изучают самостоятельно, используя традиционные приемы (слушают песни, читают книги, учебники, занимаются с репетитором, по самоучителям) и современные технологии - приложение для телефона Duolingo или другие приложения для изучения 
языков, программу “Rosetta store”, в Фейсбуке и на Ютубе, различные видеоуроки, телеграмм-чаты с носителями языка и т.д.

Далее были вопросы, которые касались мотивации изучения немецкого языка. На первом месте среди причин, по которым респонденты стали учить немецкий язык и посещать курсы немецкого языка - немецкая идентичность: 14\% опрошенных отметили вариант ответа "Я считаю себя немцем, поэтому должен знать немецкий язык, это естественно”. На втором месте вариант “Это язык моих предков, изучение языка - это дань уважения моей семье” - (10\%), 6\% опрошенных учат язык, потому что планируют уехать в Германию. Учат, потому что любят немецкую культуру - $2 \%$. Учат, потому что это необходимо (связано с работой и учебой) - 3\%. Также люди говорили о том, что родственники живут в Германии, поэтому нужно учить язык, чтобы было легче общаться, что язык необходим в поездках в Германию. Многим просто нравится немецкий язык, и они учат его с удовольствием.

Большинство опрошенных (35\%) считают существующую в центрах немецкой культуры традиционную форму преподавания - курсы немецкого языка, оптимальной формой. Высказались за трехступенчатые курсы, с возможностью пройти последний курс в Германии 29\%. Высказались за комбинированные курсы, с очной и заочной (онлайн) фазами 23\%. Считают оптимальным занятия с преподавателем в скайпе или на других платформах 7\%.

Следующий блок вопросов касался значимости для немцев немецкого языка. Респонденты отвечали на вопрос "Насколько важно российским немцам сохранять немецкий язык?”. Степень этой важности предлагалось оценить по 10-бальной шкале. В ответах значительно преобладал ответ “10 баллов" (более половины, 66\% поставили такую оценку). Лишь 31 человек из всех опрошенных поставил оценку от 1 до 4 баллов. Средняя оценка важности сохранения языка $-8,5$ баллов. Подавляющее большинство опрошенных хотели бы, чтобы их дети знали немецкий язык - 92\%. Затруднились ответить 7\%, отрицательно ответили менее $1 \%$.

В настоящий момент русско-немецкое двуязычие, которое воспроизводится в немецкой среде уже в течение жизни нескольких поколений, позволяет рассматривать его не только как этносоциальное явление, но в некоторой степени как этнический признак российских немцев. Являясь исторически оправданным и необходимым в связи с ростом межэтнических отношений, двуязычие ведет к уплотнению информационно-коммуникативных связей между представителями разных народов, позволяет повысить их адаптивные возможности.

Наряду с этим, развитие двуязычия ускоряет процессы межэтнической интеграции и ассимиляции, что в ряде случаев ведет к ослаблению позиций национального языка и связанной с ним культуры. В условиях иноэтничного окружения эти процессы являются неизбежными. Речь может идти лишь о темпах и масштабах языковой ассимиляции. Оптимальным является вариант естественной ассимиляции и межэтнической интеграции. Реально, в России происходила ускоренная языковая ассимиляция, что привело к неудовлетворенности запросов немецкого населения в области национального языка и национальной культуры. Не случайно, при ответе на вопрос “Может ли человек, не знающий немецкого языка, быть российским немцем?” 78\% опрошенных сказали, что да, может; затруднились ответить 11\% и 11\% сказали, что это невозможно.

Другими словами, сегодня невозможно жить в России и не знать русского языка. Но можно быть немцем, не зная немецкого языка. С одной стороны, существует 
множество примеров, когда люди не владеют языком, но продолжают считать себя немцами, например, в США и Канаде. Но с другой стороны, незнание языка придает негативный оттенок идентичности, люди осознают свою неспособность приобщиться в полной мере к культуре своего народа. Как сказал один из респондентов: “Я немец, безусловно, и всегда говорю, что я немец, но мне очень стыдно, что я не знаю немецкого языка. И винить в этом я могу только себя. Сейчас хожу на курсы, учу язык, но тяжело, надо было это делать раньше”. Таким образом, существует разрыв между этнической идентичностью и этническим языком, что отрицательно сказывается и на характере идентичности.

При проведении опроса важным было понять языковые потребности российских немцев, поэтому был задан вопрос “Что нужно предпринять, чтобы российские немцы начали изучать немецкий язык?”. Большинство респондентов считает, что необходимо разработать государственные программы по поддержке немецкого языка $-56 \%$. Половина опрошенных считает, что необходимо повышать качество преподавания немецкого языка в учебных заведениях - 50\%. На третьем месте оказался вариант "Проводить больше языковых курсов" - 34\%. Многие считают, что сейчас условия для изучения немецкого языка есть, и тот, кто хочет изучать немецкий язык, вполне может это делать, было бы желание. Поэтому нужно повышать мотивацию, проводить информационную работу с родителями, проводить более активную работу в Центрах немецкой культуры.

В заключение можно отметить следующие тенденции в развитии русско-немецкого билингвизма российских немцев:

По сравнению с периодом до начала массовой эмиграции, выросла доля немцев, не владеющих немецким языком совсем. Остается более или менее стабильной доля тех, кто владеет немецким языком свободно (за счет развития разных форм преподавания немецкого языка - курсы, кружки). Самая высокая языковая компетентность наблюдается у людей пожилого возраста, за счет того, что немецкий язык у большинства из них был первым языком говорения, и за счет сохранения родного языка в их семьях. Самая низкая компетентность у людей среднего возраста, эти люди в основном понимают немецкий язык, но не говорят, не пишут и не читают по-немецки, потому что возможности изучать немецкий язык у них были ограничены.

Молодежь сейчас изучает немецкий язык уже не как родной, а как иностранный. Изменилась сфера употребления немецкого языка: если раньше в основном говорили по-немецки в семьях с родителями, то в настоящее время по-немецки говорят в национально-культурных центрах, на мероприятиях, в Российско-Немецких домах, лингвистических лагерях, в поездках в Германию. Снижается роль диалектов. Раньше употреблялись в основном диалекты в разговорной речи, в настоящее время все больше людей немецкий язык изучают в его литературной форме, как нормированный, стандартный немецкий язык. Среди тех, кто владеет диалектом, больше всего говорящих на платтдойч, что связано с большим количеством меннонитов в составе немцев в России и сохранением изолированных религиозных общин меннонитов (в основном в Сибири).

Русским языком владеют все российские немцы, много людей двуязычных, которые говорят и по-русски, и по-немецки, употребляют языки в зависимости от ситуации. Снижается доля тех, кто считает немецкий язык родным, сейчас это 10\% (в 1989 г. - почти 50\%). Частота использования немецкого языка зависит от окружения на работе и от употребления языка в семье. Самая высокая степень употребления немецко- 
го языка - в сельской местности, там, где сохраняются немецкие поселения в Сибири. Самая низкая - в крупных городах, где немцы живут дисперсно. Употребление немецкого языка зависит не столько от региона России, сколько от условий развития языка: преподается ли немецкий язык в школе, есть или нет языковые курсы, есть или нет национально-культурный центр, сельская местность или город. Наиболее развитая система преподавания, начиная с раннего обучения немецкому языку, создана в немецких национальных районах в Сибири (в Омской области и на Алтае).

Рассматривая русско-немецкий билингвизм в динамике, можно отметить определенную стабилизацию. Если по результатам опроса 2009 г. очевидным было резкое падение языковых компетенций в области немецкого языка по сравнению с периодом 1990-х гг., то разница результатов опроса 2009 и 2020 гг. не принципиальная. Никакого значительного снижения знания, владения немецким языком не наблюдается. Напротив, сейчас появилось большое количество возможностей для изучения языков в виде интернет-ресурсов, приложений, онлайн-курсов. Инструменты для сохранения немецкого языка и условия для его использования есть, их предоставляют сегодня не только общественные организации, но и разнообразные Интернет-сообщества, образовательные структуры и многие другие. Поэтому главными ответственными лицами за сохранение одной из ярких особенностей этнических характеристик немцев в России - билингвизма - являются сами представители народа, которые должны ответить себе на вопрос - хотят ли они быть частью этнического, культурного и языкового многообразия страны, и, что они для этого делают.

\section{Источники и материалы}

Итоги переписи 2009 - Итоги переписи населения Республики Казахстан 2009 года. Агентство Республики Казахстан по статистике. https://web.archive.org/web/20100628101359/ http://www.stat.kz/p_perepis/Pages/n_04_02_10.aspx (дата обращения: 23.11.2020).

Национальный состав 2010 - Национальный состав и владение языками, гражданство. Всероссийская перепись населения 2010. https://rosstat.gov.ru/free_doc/new_site/perepis2010/ croc/perepis_itogi1612.htm (дата обращения: 23.11.2020).

Национальный состав 2002 - Национальный состав населения. Всероссийская перепись населения 2002. http://www.perepis2002.ru/index.html?id=17 (дата обращения: 23.11.2020).

Национальный состав 1989 - Национальный состав населения по республикам СССР. Всесоюзная перепись населения 1989 года. http://www.demoscope.ru/weekly/ssp/sng_nac_89.php (дата обращения: 23.11.2020).

Реестр 2020 - Реестр немецких поселений России. https://siedlung.rusdeutsch.ru/ru (дата обращения: 23.11.2020).

\section{Научная литература}

Александров О. А., Богословская 3.М. Немецкий “Островной” говор Томской области. Томск: Изд-во Томского Политехнического университета, 2008. $182 \mathrm{c.}$

Байкова О.В. Функционирование немецких диалектов в условиях межъ- и внутриязыкового взаимодействия в рамках языкового острова (теоретические проблемы и полевые исследования в Кировской области): Дис. док. фил. наук. Нижний Новгород: Нижегородский государственный лингвистический университет, 2012. 450 с.

Дингес Г.Г. К изучению говоров Поволжских немцев (Результаты, задачи, методы). Ученые Записки Саратовского Государственного Университета, 1925. Т.4. Вып. 3. С. 299-313.

Дульзон А.П. Проблемы скрещения диалектов по материалам языка немцев Поволжья. Известия Академии наук Союза ССР. Отделение литературы и языка, 1941. № 3. С. 82-96. 
Дятлова В.А. Тенденции развития морфологического строя контактирующих верхненемецких диалектов в условиях иноязычного окружения: Автореф. дис. канд. фил. наук. Ленинград: Изд-во Ленинградский государственный университет, 1988. 16 с.

Жирмунский В.M. Немецкая диалектология. М.-Л.: Академии наук СССР, 1956. 636 с.

Либерт E.A. Письменность языка меннонитов Plautdietsch. Вестник Новосибирского государственного университета, 2019. T.17. № 3. С. 32-41. DOI 10.25205/1818-7935-2019-17-3-32-41

Минор А.Я., Замогильный С.И., Тетюев Л.И. (под ред.) Диалект Екатериненштадта: истоки и развитие. Саратов: Изд-во Саратовский источник, 2014. 189 с.

Минор А.Я., Тетюева Л.И. (под ред.). Итоги развития языковых вариантов поволжских немцев в первой половине ХХ века. Саратов: Изд-во “Саратовский источник”, 2016. 218 с.

Москалюк Л.И. Немецкие диалекты на Алтае: Дис. доктора фил. наук. Барнаул: Барнаульский государственный педагогический университет, 2002. 499 с.

Смирнова Т.Б., Киссер Т.С. Многообразие немцев России. Уральский исторический вестник, 2017. № 2 (55). C. 44-53.

Смирнова Т.Б. Результаты этносоциологического опроса и мониторинга общественных организаций российских немцев // Немцы новой России: проблемы и перспективы развития. Материалы 2-й международной научно-практической конференции "Немцы новой России: проблемы и перспективы развития" (7-9 сентября 2009 г. г. Москва) / отв. ред. А.А. Герман. М.: “МСНК-пресс", 2010. С. 6-59.

Смирнова Т.Б. Этносоциологический мониторинг языковых процессов и языковой работы // BiZ-Bote. 2015. № 2. C. 24-29.

Фролова Н.А. Специфика развития островных говоров в условиях немецко-русского билингвизма: на материале говоров деревни Гебель Камышинского района Волгоградской области: Дис. канд. ист. наук. Саратов: Саратовский государственный университет им. Н.Г. Чернышевского, 1999. 169 с.

Berend N. Russlanddeutsches Dialektbuch: die Herkunft, Entstehung und Vielfalt einer ehemals blühenden Sprachlandschaft weit außerhalb des geschlossenen deutschen Sprachgebiets. Halle: Projekte-Verlag. Cornelius, 2011. 229 p.

Smirnova, T.B. and E.A. Shlegel*

\section{Bilingualism of the Russian Germans (According to the Sociological Surveys)}

DOI: $10.33876 / 2311-0546 / 2021-53-1 / 149-165$

Various factors impact on lingual processes of the Russian Germans. They are: heterogeneity of ethnic community, dispersed type of settlement for the most Germans and, at the same time, preserving the areas of dense settling in rural parts of the country. Other factors include: varying understanding of the "mother tongue" category and increasingly growing role of non-governmental organizations of the Russian Germans that pursue a goal-oriented policy dedicated to identity protection and maintenance of the German language. Affected by these factors the language of the Russian Germans experienced significant transformations. The Russian-German bilingualism, as a specific trait of lingual situation of the Germans living in Russia, obtained new forms. The German language gradually lost its practical functions and is increasingly turning into an ethnical symbol. The Russian language has become, on the other hand, a general tool of commonplace communication. The choice of language (German or Russian) for communication ended up depending on a particular situation, lingual environment, professional sphere and participation in non-governmental organizations' activity. In order to trace the dynamics of lingual processes the method of sociological surveys was applied. The method provides an opportunity to study peoples living in lingual borderland more thoroughly. Surveys of the Germans are being held by The International union of German 
culture once in ten years. The article provides insight into the results of the last two large-scale surveys that were conducted in 2009 and 2020. Their common goal was to analyze the state and trends of ethnocultural development of the Russian Germans. The separate module of questions mentioned in the article was dedicated to the language of the Russian Germans. The authors focused on such factors as mother tongue recognition, level of proficiency in one or another language, the field and forms of languages' usage and assessment of teaching German in educational institutions. Dynamic of ethno-lingual processes revealed in the article provides an insight into the lingual situation and an outlook to the development of RussianGerman bilingualism of the Russian Germans.

Keywords: bilingualism, Russian Germans, ethno-lingual processes, sociological survey

For Citation: Smirnova, T.B. and E.A. Shlegel. 2021. Bilingualism of the Russian Germans (According to the Sociological Surveys). Herald of Anthropology (Vestnik Antropologii) 1 (53): 149-165.

* Smirnova, Tatiana B. - Doctor of Hist., Vice-Rector for Academic Affairs, Dostoevsky Omsk State University (644053 Omsk, Neftezavodskaya st., 11, Russian Federation). E-mail: SmirnovaTB@omsu.ru

Shlegel, Elena A. - Post-Graduate Student, Vice-Rector for Academic Affairs Assistant, Dostoevsky Omsk State University (644053 Omsk, Neftezavodskaya st., 11, Russian Federation). E-mail: ShlegelEA@omsu.ru

The research was supported by the Russian Foundation for Basic Research (RFFI, project No. 17-29-09152)

\section{References}

Aleksandrov, O.A., Bogoslovskaya, Z.M. 2008. Nemetskii “Ostrovnoi” govor Tomskoi oblasti [German "Island" mode of speech of the Tomsk Region]. Tomsk: Izdatel'stvo TPU.

Baikova, O.V. 2012. Funktsionirovanie nemetskikh dialektov v usloviyakh mezh- $i$ vnutriyazykovogo vzaimodeistviya v ramkakh yazykovogo ostrova (teoreticheskie problemy i polevye issledovaniya $v$ Kirovskoi oblasti) [Functioning of German dialects within the conditions of inter- and intralingual flow of communication as part of lingual island (theoretical problems and field studies in the Kirov Region)]. Doctoral (Philology) Dissertation, Nizhny Novgorod: Linguistics University of Nizhny Novgorod.

Dinges, G.G. 1925. K izucheniyu govorov Povolzhskikh nemtsev (Rezul'taty, zadachi, metody) [To the mode of speech of the Germans along the Volga (Results, goals, methods)]. Uchenye zapiski SGU [Scientific Notes of Saratov State University] 4 (3): 299-313.

Dulzon, A.P. 1941. Problemy skreshcheniya dialektov po materialam yazyka nemtsev Povolzh'ya [Problems of hybridization of the dialects accoding to the lingual materials of the Germans along the Volga]. Izvestiya Akademii nauk Soyuza SSR. Otdelenie literatury i yazyka [Proceedings of the Academy of Sciences of USSR. Section of literature and language] 3: 82-96.

Dyatlova, V.A. 1988. Tendentsii razvitiya morfologicheskogo stroya kontaktiruyushchikh verkhnenemetskikh dialektov $v$ usloviyakh inoyazychnogo okruzheniya [Tendencies of development for morphological base of connecting High German dialects under the conditions of foreign-language environment]. Extended Abstract of Candidate (Philology) Dissertation, Leningrad: Izdatel'stvo LenGU.

Zhirmunski, V.M. 1956. Nemetskaya dialektologiya [German dialectology]. Moscow-Leningrad: Akademiya nauk USSR.

Libert, E.A. 2019. Pis'mennost' yazyka mennonitov Plautdietsch [Writing system of Mennonite language Plautdietsch]. Vestnik NGU [Novosibirsk State University Bulletin] 17 (3): 32-41. Doi: 10.25205/1818-7935-2019-17-3-32-41.

Minor, A.Ya., S.I. Zamogil'nyi, and L.I. Tetyueva, eds. 2014. Dialekt Ekaterinenshtadta: istoki $i$ razvitie [Dialect of Yekaterinenstadt: sources and development]. Saratov: Izdatel'stvo 
Saratovskii istochnik.

Minor, A.Ya., L.I. Tetyueva, eds. 2016. Itogi razvitiya variantov povolzhskikh nemtsev v pervoi polovine XX veka [Development results of lingual variations of the Germans along the Volga in the first half of XX century]. Saratov: Izdatel'stvo Saratovskii istochnik.

Moskalyuk, L.I. 2002. Nemetskie dialekty na Altae [German dialects in Altai]. Doctoral (Philology) Dissertation, Barnaul, Izdatel'stvo Barnaul GPU.

Smirnova, T.B., Kisser, T.S. 2017. Mnogoobrazie nemtsev Rossii [Diversification of Russian Germans]. Ural'skij istoricheskij vestnik 2 (55): 44-53.

Smirnova, T.B. 2010. Results of ethno-sociological survey questionnaire and monitoring of nongovernmental organizations of Russian Germans. Nemtsy novoi Rossii: problemy i perspektivy razvitiya. Proceedings of the Second International Research-to-Practice Conference "Germans of contemporary Russia: problems and perspectives of development" (Moscow, Russia, September 7-9, 2009), edited by A.A. German, 6-59. Moscow: MSNK-press.

Smirnova, T.B. 2015. Etnosotsiologicheskii monitoring yazykovykh protsessov i yazykovoi raboty [Ethno-sociological monitoring of lingual processes and lingual work]. BiZ-Bote 2: 24-29.

Frolova, N.A. 1999. Spetsifika razvitiya ostrovnykh govorov $v$ usloviyakh nemetsko-russkogo bilingvizma: na materiale govorov derevni Gebel'Kamyshinskogo raiona Volgogradskoi oblasti [Specifics of development of island modes of speech in the setting of the German-Russian bilingualism: a case study of modes of speech in the village Gebel' of Kamyshinskii district of the Volgograd Region] Candidate (History) Dissertation, Saratov, Izdatel'stvo SGU.

Berend, N. 2011. Russlanddeutsches Dialektbuch: die Herkunft, Entstehung und Vielfalt einer ehemals blühenden Sprachlandschaft weit außerhalb des geschlossenen deutschen Sprachgebiets. Halle: Projekte-Verlag. Cornelius. 